\title{
The Inescapable Association between Nature and Bengali Nationalism in Jibanananda Das's Ruposhi Bangla
}

\author{
Nahid Afroz ${ }^{1}$, Sheikh Shareeful Islam ${ }^{2 *}$ \\ ${ }^{1}$ Assistant Professor, English Discipline, Khulna University, Khulna-9208, Bangladesh \\ ${ }^{2}$ Lecturer, Department of English, Northern University of Business and Technology Khulna, Shibbari Mor, \\ Sonadanga, Khulna-9100, Bangladesh
}

*Corresponding Author: Sheikh Shareeful Islam, Lecturer, Department of English, Northern University of Business and Technology Khulna, Shibbari Mor, Sonadanga, Khulna-9100, Bangladesh

\begin{abstract}
Jibanananda Das, in his poetry, exhibits a deep-rooted passion for Bengal. His volume Ruposhi Bangla is a manifestation of his powerful feeling for the nation. To him, perhaps, the most attractive thing is the imagery of Bengal's nature. However, in spite of receiving multidimensional criticism on different aspects i.e., adoration for natural beauty, Das 's poetry receives critique on nature and nationalism only inadequately. There exists, therefore, the question-whether Das's poetry show any association between the nature and nationalism of Bengal. This paper attempts to delve into this matter by re-visiting his poetry. Our findings would proffer, initially, that there should be no confusion about the type of nationalism, as for Das's poetry. Additionally, we would argue that Bengali nationalism is expressed well through his extreme feeling for Bengal's nature. We have focused particularly on the poetry of Ruposhi Bangla in this study.
\end{abstract}

Keywords: Bengali Nationalism, Jibanananda Das, Nature, Ruposhi Bangla

\section{INTRODUCTION}

Jibanananda Das's poetry, Ruposhi Bangla in particular, showcases his inescapable bondage with nature. Ostensibly, the focus of the poems of this volume is on the celebration of nature. These poems unleash the speaker(s)' fondness for the beautiful nature of Bengal. The landscape, rivers, trees, flowers, birds, monsoons etc. are the objects of contemplation. Hence, the current knowledge accepts, to a certain extent, that this volume of poetry chiefly enunciates the speaker(s)' love for Bengal's nature. However, an inevitable point - the representation of Bengali nationalism-gets inadequate response. Moreover, in our opinion, Das's laconic expression of Bengali nationalism in relation to his affection for nature demands sufficient critical thinking. This research finds it thought-provoking to discuss such issues in detail. To the best of our knowledge, the existing scholarships do not offer satisfactory definite understanding as for the projection of Bengali nationalism through nature. This paper deals with, primarily, the covert yet inescapable illustration of Bengali nationalism in the aforementioned volume. Additionally, at a deeper level, our paper focuses on the manifestation of such nationalism (Bengali) with the help of nature. We think our study would contribute to a better exposition of the relationship between Bengali nationalism and Bengal's nature in these poems of Das. In the following sections we would argue that these poems encompass a pure Bengali nationalism, and we would also see how this gets illumination through a deeply-seated admiration of Bengal's nature.

\section{DISCUSSION}

The seminal poems in Ruposhi Bangla depict the natural beauty of Bengal in a way that one finds Das as a pure child of nature. His eagerness to return to nature and earnest wish to be in the lap of nature are, seemingly, the subject matters of these poems. Yet, beneath the verse lines there exists a profound expression of Bengaliness. The rendering of these poems paves the way for one to recapitulate these into a well-structured nationalism. To our opinion, there is no doubt about the type of such nationalism - this is Bengali nationalism. Because, whatever object of nature is featured by Das's speaker(s), is in a blend with a powerful feeling for Bengal. Though critics often accredit Das as an essential spirit of modernism in Bengali poetry of the previous century, one can find him 
commendable for his demonstration of Bengali nationalism through the projection of nature. Of course, one can enquire of the existence of Bengali nationalism in Das's poetry, keeping in mind that nationalism requires one's profound attachment with one's nation. However, this attachment culminates in one's association with every object of the nation - different components of nature are therefore objects of nation. Another point is that "life and poetry are different expressions of the same entity" (qtd in Guha 22). Therefore, if one thinks that nationalism would find manifestation through the lives of the people, he/she can also find it in poetry. Das's poems reveal one's intimate association with the nation. To our opinion, this association leads to nationalism. In this respect, Abul Mansur Ahmed argues, "nationalism is a spiritual concept" (151), and that "... as the approval and existence of the spirit is beneficial to an individual, it is the same for a nation" (151). Thinking in this way, an individual's essence is mirrored in that of his/her nation and vice versa. Therefore, the spirit of a nation can flourish in the image of an individual (Ahmed 152). When Das proclaims in "I Have Seen Bengal's Face", "I have seen Bengal's face, and seek no more, / The world has not anything more beautiful to show me" (1-2), one notices the speaker's explicit admiration for the nation. It is his/her expression of Bengaliness. Such Bengali identities abound in the poems of Ruposhi Bangla. Another instance can be from "Beautiful Bengal"- "I'll come lovingly again to Bengal's rivers, fields, farmlands, / To the green wistful shores of Bengal lapped by Jalangi's waves" (8-9). Here also, like the preceding one, Das's speaker finds comfort in the lap of Bengal's nature. Such a powerful feeling for a nation, in fact, culminates in nationalism - here it is Bengali nationalism. Das's nationalism is "imaged in terms of landscape and spaces" (Nayar 77).

Another worth considering issue is that of the association between nationalism and literature. To be precise, the question may arise whether literature plays any role in forming or obliterating the concept of nationalism in or from the individuals' mind. We find John McLeod's reiteration of Fanon's idea that literature can and does contribute to the construction of a "national consciousness" (91) worth considering. Therefore, different genres of literature exhibit, both implicitly and explicitly, the essence of nationalism in some cases. Accordingly, writers from different parts of the world delineate their respective nationalism in their writings-W. B. Yeats in Ireland, Wole Soyinka in Africa, Tagore in Bengal are to name a few. They show different types of nationalism. Similarly, Das, through his speaker(s), depicts Bengali nationalism - though his subject matter and the way of expression are different from those of the other mentioned writers.

One can, however, enquire of the absence of violence, struggle, and sacrifice for one's nation in Das's poetry, and therefore would question the manifestation of nationalism in these poems. It is, to a certain extent, accepted that true nationalism requires the inhabitants' active participation in the crucial issues of the nation - the issues regarding the nation's survival, freedom, and cultural intactness. Concern for the nation's wellbeing requires extreme stance against any type of assault from any outer power and this leads to an uncompromising sacrifice from the inhabitants. This type of nationalism - absent in Das's Ruposhi Bangla - is quite often seen in Bengali writers. Amitav Ghosh's The Shadow Lines (1999) depicts that the narrator's grandmother, one of its major characters, relishes an "anti-imperialist" (Nuruzzaman and Islam 2) nationalism. Additionally, she affirms that she should "make a sacrifice" (2) for the nation, and she does so. However, there are also critiques against such nationalism. For example, Leela Gandhi mentions that the "anti-colonial struggles in Asia and Africa" as a "deluded" (108) nationalism. She also mentions ". . . nationalism outside the West can only be premature and partial — a threat to the enlightened principles of the liberal state and, thereby, symptomatic of a failed or 'incomplete' modernity" (Hegel qtd. in Gandhi 108).This categorical argument posits Bengali nationalism in a vulnerable state. However, this is a counterpoint to our research. We think that nationalism in Das's poetry is unquestionably outside of the West, yet it is complete in itself and mature. The manifestation of this nationalism is not a threat to any state. In spite of showing any type of struggle, Das's poems denote a spectacular presence of Bengal. There is a gulf of difference between the violent anti-colonial nationalism of Bengal and Das's nationalismalbeit both of them belong to the same period, to a certain extent. One of the major tenets of the nationalist writings is that these emphasize "the relationship between the people and the land in order to underline the illegitimate intrusion of the colonizers, asserting a "unity between people and place""

\footnotetext{
${ }^{1}$ The translation is ours.

2 The translation is ours.
} 
(McLeod 92). To our opinion, Das's Ruposhi Bangla is a stunning example of this. By employing several nature oriented imagery Das tries to posit people and landscape in a close bond. For example, his speaker in "The World Busies Itself" declares, "I've built my home in Bengal's rural scene, / Where ravens fly into palmyra groves in evenings" (4-5). The speaker tries to express that when "people hustle for success and power" (1), he/she is obsessed only with Bengal's land. What appeals $\mathrm{him} /$ her most is "Bengal's rivers, fields, (and) flowers" (15). Das's effort to associate the people and the landscape of Bengal becomes more effective when the speaker in "Beautiful Bengal" sings, "Perhaps a little boy will be scattering parched rice in some grassy yard, / In the muddy Rupsha river some boy will be rowing a boat" (12-13). Moreover, the speaker wants to be intermingled with Bengal's nature. Das makes the speaker of "Beautiful Bengal" say "I'll come again to the banks of the Dhanshiri - to this land / Perhaps not as a human - may be as a white-breasted / Shankachil or a yellow-beaked shalik" (1-3).

Das does not offer any "revolutionary vocabulary" (Gandhi 111) in Ruposhi Bangla to express nationalism. His speaker(s) rather present pleasant nature centric words and phrases which, on the one hand, express an inevitable association to Bengal, and therefore Bengali nationalism. On the other hand, the nationalism in Das's poetry possesses the "capacity to heal the historical wounds inflicted by the 'Manichean' structure of colonial culture" (Gandhi 111), as is also the case with Franz Fanon's The Wretched of the Earth. Das wants to see Bengal's face "without the frames of reference used by the colonial masters" (Nayar 68). For example, Das's speaker sings in "There is a Land", "There is a land in this world - incomparably beautiful and sad" (1) - he/she is denoting Bengal. This oxymoron shows how this land is associated with the happiness and sorrow of the people of Bengal. The speaker will find solace when he/she would be merged with Bengal's nature. Das, in "The Day I Leave You All", makes his speaker further say, "That day will I have no sorrows-living in a land where the dust / Smells of moist grass, where Bengalis throng everywhere-" (5-6), because "these warmed my (the speaker) soul" (9). Therefore, through his speaker, Das tries to affirm his fondness for Bengal. His chief concern is Bengali nationalism. He suffers from communal violence and its aftermath during the partition of Bengal, yet he always clings to Bengal - a unified Bengal. His poem "1946-47", though out of the volume Ruposhi Bangla, focuses on such issue. Fakrul Alam, in this respect, opines that in this poem:

... he (Das) broods on the communal strife, chaos, and diasporas that accompanied the partition of India in general and Bengal in particular. Das himself had been uprooted by historical events, and had moved from the Muslim majority district of Barisal to Calcutta, where

Hindus were in a majority. But Calcutta too was in tumult and riven by religious riots ... . (115)

Yet, his attachment to Bengal does not fade up. To him, perhaps, Bengal is a single entity, which is his inspiration for living. His poems showcase the same opinion as Ahmed's - "Bengal is never partitioned"3 (153). The reason behind this is, perhaps, "like the self of an individual the self of a nation also is indivisible" (Ahmed 154).

Another point to address is whether there are really different types of nationalism or not. Benedict Anderson "refuses to recognize the possibility of alternative, variant, and different nationalisms" (Gandhi 114), in this regard. However, our opinion is in a contrast to his argument and concurs with that of Gandhi, who disavows Anderson's idea of homogenous nationalism. Accordingly, Das's nationalism is explicitly different from violent anti-colonial or anti-imperialist nationalism. Moreover, as for this issue Das is in a contrast to Tagore, for whom "nationalism was a system of illusions, designed progressively to homogenize and normalize small, individual sentiments of insurgency" (Gandhi 121). Additionally, Das's nationalism is different also from that of W.B. Yeats, an Irish nationalist poet. The latter, for example in "Easter 1916", celebrates a revolution as a mode of nationalism. Contrary to these, Das depicts a soft nationalism which gets culmination through his admiration for Bengal's nature. Sinha makes an attempt to compare Yeats' poetry to that of Das:

Das, unlike Yeats, appeared to be disinterested in contemporary political movements. Nevertheless, a sense of nationalism pervaded their poems. In Yeats's case, it was the fusion of both political and cultural; in Das's case, it was mere cultural, more akin to the aspects of Nature. (168)

\footnotetext{
${ }^{3}$ The translation is ours.

${ }^{4}$ The translation is ours.
} 
Thus, Das's idea of Bengali nationalism gets manifestation through his use of nature. In his poetry the image of nature and landscape expresses his deep sense of Bengali identity.

A further debate may, however, arise between Bengali nationalism and Bangladeshi nationalism in Das's poetry. In Ruposhi Bangla, Das celebrates Bengal's nature to a sophisticated level. His deeplyseated association to nature, to a certain extent, unleashes his covert yet inevitable consciousness for his nation and national identity. This, as our article has already argued, finds its way to a soft nationalism. Now, the question would what one should call Das's nationalism-Bengali or Bangladeshi? To our opinion, the nationalism that Das expounds is Bengali nationalism. Our logic behind this hypothesis is that Das speaks for Bengal's nature in its entirety. The poems in Ruposhi Bangla focus on the association between the speaker(s) and Bengal's nature beyond the limits of religion or geopolitical border. These poems do not differentiate between the nature of East Bengal, now Bangladesh, and that of West Bengal. To support our argument, we find Kabir Chowdhury's remark worth mentioning - the deliberation, as for Bengal's nationalism, is a "needless, valueless, and confusing debate"5 (197). In addition, Safor Ali Akanda's postulation concurs with that of ours. He thinks that "in spite of being Anglo-Indian citizen, during the British reign, I (the writer) was Bengali; this Bengali identity persisted intact during the Pakistani rule as well; still, after the liberation of Bangladesh, my (the writer) national identity remains unaffected"6 (11). Therefore, one notices that the nationalism that Das's poetry depicts is, in fact, Bengali nationalism. We think, Das, through his speaker(s), attempts to demonstrate his Bengaliness, and consequently Bengali nationalism. Such an effort gets culmination through his association to nature.

\section{CONCLuSion}

The poems in Ruposhi Bangla admire the natural beauty of Bengal. One can consider Das's speaker(s) as a true child of nature, who always wish to live in a close contact with nature. Bengal's landscape, rivers, flowers, trees, birds etc. are the only space that can provide the speaker(s) with peace, stability, and identity. Our paper finds that Das expresses his own deep-seated association with Bengal's nature by means of his speaker(s). However, our paper also argues that these poems, by rendering Das's inescapable bond with nature, speak for Bengali nationalism-though soft in temperament. We have tried to justify that the poems in Ruposhi Bangla contain the essence of Bengali nationalism which gets manifestation through Das's appreciation of Bengal's nature. We think that these findings would shed a new light on the poems of this volume. Our paper, in a sense, would problematize the accepted notions about these poems in the existing scholarships. This can open a new avenue to read Das's poetry going beyond the simple admiration of natural beauty. That these poems contain the essence of a soft nationalistic belief would be a new issue that deserves sufficient critical thinking. However, we hope that our research would take sufficient criticisms from the future researchers, who would find these issues interesting and should respond to these more adequately.

\section{REFERENCES}

[1] Guha, Bhumendra. Selection of Jibanananda Das: Original Texts. Dhaka: Bengal Publications Ltd., 2015. Print.

[2] Ahmed, Abul Mansur. Culture of Bangladesh. Dhaka: Ahmed Publishing House, 1995. Print.

[3] Alam, Fakrul, trans. Jibanananda Das: Selected Poems. By Jibanananda Das. Dhaka: The University Press Ltd., 2010. Print.

[4] Nayar, Pramod, K. Postcolonial Literature: An Introduction. Noida: Pearson, 2013. Print.

[5] McLeod, John. Beginning Postcolonialism. New Delhi: Viva Books, 2010. Print.

[6] Nuruzzaman, Md., and Sheikh Shareeful Islam. "The Illuminated Lines in Amitav Ghosh's The Shadow Lines.” Khulna University Studies 13.1 (2016): 1-8. Print.

[7] Gandhi, Leela. Postcolonial Theory: A Critical Introduction. New Delhi: Oxford University Press, 2013. Print.

[8] Chowdhury, Kabir. "Identity of the Bengalis: Cultural Perspective." Identity of the Bengalis. Ed. Safor Ali Akanda. Rajshahi: Institute of Bangladesh Studies, 1991. 183-206. Print.

\footnotetext{
${ }^{5}$ The translation is ours.

${ }^{6}$ The translation is ours.
} 
The Inescapable Association between Nature and Bengali Nationalism in Jibanananda Das's Ruposhi Bangla

[9] Akanda, Safor Ali. Identity of the Bengalis. Rajshahi: Institute of Bangladesh Studies, 1991. Print.

[10] “Jibanananda Das: Defining 20th century Bengali Poetry." The dailystar.net. The Daily Star, 22 Oct. 2010. Web. 19 Feb. 2017.

[11] Sinha, Manas. "Selected Poems of Yeats: Close Reading in the Perspective of Their Impact on Jibanananda Das' Poetic Self." The Echo 1.4 (2013): 168-176. PDF file.

\section{AUTHORS' BIOGRAPHY}

Nahid Afroz completed her BA (Hon's) and MA in English from Khulna University. She is an assistant professor of English at Khulna University. Her fields of research interest are South Asian English Writing, Feminism, Post colonialism etc.

Sheikh Shareeful Islam completed his BA (Hon's) and MA in English from Khulna University. He has been working as a Lecturer in English at Northern University of Business and Technology Khulna. His fields of research interest are ecocriticism, animal studies, translation studies, postcolonial literature etc

Citation: Nahid Afroz, Sheikh Shareeful Islam. "The Inescapable Association between Nature and Bengali Nationalism in Jibanananda Das's Ruposhi Bangla" International Journal on Studies in English Language and Literature (IJSELL), vol 7, no. 2, 2019, pp. 10-14. doi: http://dx.doi.org/10.20431/2347 -3134.0702002.

Copyright: (C) 2019 Authors. This is an open-access article distributed under the terms of the Creative Commons Attribution License, which permits unrestricted use, distribution, and reproduction in any medium, provided the original author and source are credited. 